\title{
Phenotypic Variations in the Behavior of Sip1 Knockout Mice
}

\author{
DOI: $10.17691 / \mathrm{stm} 2018,10.2 .02$
}

Received November 23, 2017

1.1. Belousova, PhD, Senior Researcher, Experimental Modeling Department, Central Scientific

Research Laboratory ${ }^{1}$; Senior Researcher, Brain Development Genetics Laboratory, Institute of Neuroscience ${ }^{2}$;

N.M. Zhidkova, PhD Student, Department of Neurotechnologies, Institute of Biology and Biomedicine2; Junior Researcher, Brain Development Genetics Laboratory, Institute of Neuroscience;;

E.V. Borisova, Junior Researcher, Brain Development Genetics Laboratory, Institute of Neuroscience ${ }^{2}$;

E.A. Epifanova, Junior Researcher, Brain Development Genetics Laboratory, Institute of Neuroscience ${ }^{2}$;

V.A. Salina, Junior Researcher, Brain Development Genetics Laboratory, Institute of Neuroscience;;

S.A. Tutukova, Junior Researcher, Brain Development Genetics Laboratory, Institute of Neuroscience ${ }^{2}$;

R.D. Lapshin, PhD, Associate Professor, Head of Experimental Modeling Group, Central Scientific

Research Laboratory';

A.A. Babaev, PhD, Associate Professor, Department of Neurotechnologies, Institute of Biology and Biomedicine ${ }^{2}$;

Senior Researcher, Brain Development Genetics Laboratory, Institute of Neuroscience;

I.V. Mukhina, DSc, Professor, Head of Central Scientific Research Laboratory';

Head of the Department of Normal Physiology named after N.Y. Belenkov'; Professor, Department

of Neurotechnologies, Institute of Biology and Biomedicine2; Head of the Center for Translational Technology2;

V.S. Tarabykin, DSc, Professor, Director, Institute of Cell Biology and Neurobiology $\mathrm{CCM}^{3}$;

Head of Brain Development Genetics Laboratory, Institute of Neuroscience ${ }^{2}$

${ }_{1}^{1}$ Privolzhsky Research Medical University, 10/1 Minin and Pozharsky Square, Nizhny Novgorod, 603005, Russia;

${ }^{2}$ Lobachevsky State University of Nizhni Novgorod, 23 Prospekt Gagarina, Nizhny Novgorod, 603950, Russia;

${ }^{3}$ Charité — Universitätsmedizin Berlin, 1 Charitéplatz, Berlin, 10117, Germany

The aim of the study was the behavioral phenotyping of mice homo- and heterozygous for the Sip1 gene, which plays an important role in the development of the mammalian cerebral cortex.

Materials and Methods. The study was performed on mice hetero- and homozygous for the Sip1 gene; these animal models were developed using the Cre recombination method. At an age of 20-30 days, all animals were exposed to a high-intensity sound to identify predisposition to audiogenic epilepsy. At an age of two months, the males were tested for their general physical health and behavioral phenotypes. The tests included a neurological and sensorimotor assessment, an evaluation of anxiety using the light-dark test, a study on locomotion and general exploration in the open field test, the acoustic startle response and prepulse inhibition, social activity in the Crawley's test and the learning ability as scored by the conditioned reflex of passive avoidance.

Results. Mice homozygous for the Sip1 gene never reached the age of two months. In heterozygous mice, a higher occurrence of hind limb extension reflex abnormalities, an increased level of anxiety in the light-dark test, and a decrease in social activity in the Crawley's test were found.

Conclusion. The presence of a mutant allele of the Sip1 gene leads to neurologic disorders, an increase in anxiety and a decrease in the social activity of the animals.

Key words: phenotyping; knockout; neocortex; Sip1; prepulse inhibition; Crawley's test.

\section{Introduction}

The developmental defects of the human brain are now increasingly viewed as a major cause of epilepsy, developmental delay, neurological deficits and mental retardation [1]. Recently, significant progress has been made in identifying the genes that control various stages of brain cortex development [2,3]. To further identify and characterize these genes and better understand the genetic base of cortical functions and dysfunctions, mutant mice with developmental defects of the cortex are commonly used.

The Sip1 gene encodes an important transcription factor in the mammalian cells. It plays a critical role in the regulation of epithelial-mesenchymal transition during embryogenesis and tumorigenesis [4], as well the migration of ectodermal markers in the lens formation [5]. Sip1 knockout leads to skin hypersensitivity, atrophic

Corresponding author: Irina I. Belousova, e-mail: ira.belousova@gmail.com 
scars and hypermobility of joints caused by disrupted collagen fibrillogenesis [6]. Sip1 protein is the most important transcription factor crucial for the development of the central nervous system (CNS). It has been found that mutations in the human Sip1 gene are associated with the pathogenesis of Mowat-Wilson syndrome characterized by severe mental retardation and agenesis of the corpus callosum [7]. The Sip1 gene participates in the intracortical, intercortical and cortico-subcortical connections in the murine forebrain. Its removal from post-mitotic neocortical neurons disrupts the formation of the corpus callosum, the anterior commissure and the corticospinal tract [8].

Knockout of a specific gene is a convenient model for studying the role of the gene product in a living organism. It is known that a partial mutation in the Sip1 gene modifies the NMDA and AMPA receptors in neocortical neurons in vitro. Such neurons are more sensitive to the effects of NMDA and AMPA agonists compared to wild type (WT) neurons [9]. Our studies were performed on conditional mutants where the Sip1 gene had been removed from the post-mitotic cells of the cerebral cortex. Behavioral phenotyping is a necessary step to further characterize this line of mice including the role of the Sip1 gene in the sensorimotor functions of the CNS.

The aim of the study is the behavioral phenotyping of mice homo- and heterozygous for the Sip1 gene, which plays an important role in the development of the cerebral cortex in mammals.

\section{Materials and Methods}

The animals were kept in an SPF animal facility at the Lobachevsky State University of Nizhni Novgorod. All animal experimentation met the requirements described in the Rules for the Work using Experimental Animals (Russia, 2010) and the International Guiding Principles for Biomedical Research Involving Animals (CIOMS and ICLAS, 2012); the ethical principles established by the European Convention for the Protection of Vertebrate Animals used for Experimental and Other Scientific Purposes (Strasbourg, 2006) were strictly observed. The Ethical Committee of the Lobachevsky State University of Nizhni Novgorod approved the protocol of these experimental studies on animals.

Animals. To create a line of mice with a mutant Sip1 gene, the Cre recombination method was used: the Sip1 gene flanked by the loxP sites was excised from DNA in the process of Cre expression in the neuron. The murine line with the flanked Sip1 gene was first obtained by Higashi et al. [10]. The exon 7 of the 2 kb Sip1 gene contains about half of the protein coding sequence. Deletion of exon 7 results in premature termination of translation due to a shift in the reading frame in the downstream exon 8 . In this murine line, exon 7 is flanked by the loxP sites, which leads to inactivation of the Sip1 protein after the Cre-mediated removal of this exon. To generate a conditional mutant with a deleted Sip1 gene from the post-mitotic cells of the cerebral cortex, Sip1 $\mathrm{fl} / \mathrm{fl}$ mice were crossed with NexCre mice [11-13]. In these mice, Cre recombinase is expressed under the Nex promoter, which maintains the expression only in postmitotic cells of the neocortex. Following this procedure, two groups of mutant animals have been obtained: the homozygous line (where the Sip1 gene is absent in both alleles) and the heterozygous line (where the Sip1 gene is present in one allele only).

All studies were performed using mice hetero- (+/-) or homozygous (-l-) for the Sip1 gene; their behavior was compared with the behavior of WT animals.

The audiogenic response was tested in mice aged 20 30 days; all other tests were conducted with 2-month-old mice weighing 21-25 g. After the newborn mice had been separated from their mothers, the mouse pups were kept in groups in ventilated cages (Techniplast, Italy) with a 12hour day/night cycle, at $22^{\circ} \mathrm{C}$ and $65 \%$ humidity with free access to food and water. The behavioral studies were carried out during the "day" phase between 10 am and 3 pm.

\section{Behavioral assessment tests}

Audiogenic stimulation. At an age of 20-30 days, all newborn mice (male and female) were exposed to audiogenic stimulation. The animals were placed in a glass round-bottom flask located inside a soundproof double wall box made of expanded polystyrene. After 1-minute habituation, an electromechanical bell with a sound intensity of $110 \mathrm{~dB}$ was turned on. The sound was given once and turned off immediately after the onset of a seizure; if no seizure ensued the sound was turned off in $60 \mathrm{~s}$ anyway [14]. The behavior pattern was recorded using a Microsoft LifeCam MSCR-LC-Cinema video camera (Microsoft, USA). Quantification of audiogenic seizures in response to the sound was performed according to the following scale [15]:

0 points - no response to sound for $60 \mathrm{~s}$;

1 point - the phase of the "circus movements", or motor excitation, when the animals perform uncontrolled movements in the chamber as the stimulation began;

2 points - the onset of clonic seizures when the mouse falls on its abdomen (the onset of seizures);

3 points - fall on the side, clonic seizures of the forelimbs and hind limbs;

4 points - tonic seizures of the forelimbs, clonus of the hind limbs;

5 points - tonic seizures of the fore- and hind limbs accompanied by overall rigidity.

Only 2-month-old males were selected for the further behavioral studies in adult animals in various tests in order to avoid the effects of female sex hormones and the estrous cycle phase on the behavior and learning ability of the mice [16]. The following parameters were evaluated: body weight, bald patches, physical abnormalities, fur bristling, and damaged vibrissae [17]. These tests were followed by behavioral phenotyping in the following sequence: neurological and sensorimotor studies (coordination, climbing, locomotion and orientation); 
the light-dark test (a study of anxiety); the open field test (a study of motor and exploration activity); the acoustic startle response and prepulse inhibition - PPI (investigation of sensorimotor gating); the Crawley's test (a study of sociability and preference for social novelty); the development of the conditioned reflex of passive avoidance (the learning ability).

Sensorimotor examination. The test evaluates the motor functions and some reflexes. To test the hind limb extension reflex, the mouse was suspended by the tail for $1 \mathrm{~min}$. The normal manifestation of this reflex implies extension of hind limbs; contracting one limb towards the midline of the abdomen or clasping the limbs is considered abnormal [17].

To detect a deficiency in the motor coordination and balance, a set of sensorimotor tests was used, such as the balance beam walking test. During the experiment, the time taken by the animal to perform each of the assigned tasks was recorded. The maximal time of observation was $120 \mathrm{~s}$. The mice were tested according to the following criteria:

1. General motor activity. The mouse was placed on a flat surface, and the time that has passed until the animal left a circle $30 \mathrm{~cm}$ in diameter was measured.

2. Walk on a horizontal beam. Flat beams 1, 2, and $3 \mathrm{~cm}$ wide or 3 and $0.5 \mathrm{~cm}$ round beams were used. The mouse was placed in the middle of a $50 \mathrm{~cm}$ long horizontal beam, with its ends fixed on two platforms $50 \mathrm{~cm}$ above a soft base. The time taken by the mouse to reach one of the platforms was measured. If the animal slipped off the beam, the result was considered to be $120 \mathrm{~s}$.

3 . The hanging wire test. The mouse was suspended by their forelimbs on a horizontal wire hanging between two platforms at a height of $50 \mathrm{~cm}$ above a soft base. The time before the mouse fell was measured.

4. Turning around in a cylinder. The mouse was placed into a closed cylinder $(3 \mathrm{~cm}$ in diameter and $13 \mathrm{~cm}$ long) facing the cylinder wall. The time before the animal turned around to face the opposite direction was measured

5. Turning around on an inclined screen. The mouse was placed on an inclined screen to face down the slope (a $20 \times 20 \mathrm{~cm}$ wire mesh platform fixed at an angle of $45^{\circ}$ ) at a height of $50 \mathrm{~cm}$ above the table. The time before the mouse turned around to face up the slope was measured.

The light-dark test. This experimental model designed to evaluate anxiety-related behavior is based on the earlier developed model of situational anxiety [18]. The experimental setup included the light $(25 \times 25 \times 24 \mathrm{~cm})$ and dark $(19 \times 11 \times 12 \mathrm{~cm})$ compartments connected with a partition having an opening (Panlab/Harvard Apparatus, Spain). The mouse was placed into the lit compartment with its back to the dark one and the following parameters were automatically recorded for $10 \mathrm{~min}$ : the latency of the first entry into the dark compartment, the time of staying either in the lit or dark compartments, and the number of transitions between the compartments.
The open field test. To study the motor and exploration activity of mice placed in an unfamiliar open space, we used an open field setup equipped with an infrared actimeter (Panlab/Harvard Apparatus, Spain) and the ActiTrack software. The experimental design consisted of a square arena $40 \times 40 \mathrm{~cm}$ with rims $20 \mathrm{~cm}$ high and two square frames; an infrared detection system was used to locate the animal.

The mouse was placed in the center of the arena; the animal's behavior was monitored for $5 \mathrm{~min}$. To analyze the behavioral pattern, the experimentation area was virtually divided into two zones: the central $(20 \times 20 \mathrm{~cm})$ and the peripheral ones. The following parameters were recorded: the total distance traveled, the distance traveled in each zone, the number of rearings made (total and in each zone), the average speed of movement $(\mathrm{cm} / \mathrm{s})$, as well as the number of defecations and urinations, which characterize the level of "emotionality" of the animal.

The acoustic startle reflex and prepulse inhibition. The setup for studying the startle reflex (Panlab/Harvard Apparatus, Spain) is able to produce any combination of sounds, noises and white noise. An experimental animal was placed into a special box and fixed there in proper position. The level of startling was recorded by measuring the change in pressure exerted by the animal on the pad below it. Recording was performed automatically using the Packwin software package (Panlab/Harvard Apparatus, Spain). After a 3-minute period of habituation against the background of white noise $(60 \mathrm{~dB})$, the following signals were given:

no pulse -5 times; prepulse $(80 \mathrm{~dB})-5$ times; pulse $(100 \mathrm{~dB})-5$ times;

recurrent series of prepulse/pulse signals with an interval of $60 \mathrm{~ms}-5$ times.

These signals were given randomly, and the animal startles were recorded. The results were expressed as PPI calculated by the formula:

$$
\mathrm{PPI}=(\mathrm{P}-\mathrm{PP}) / \mathrm{P} \cdot 100 \% \text {, }
$$

where $P$ is the startle response to the pulse and $P P$ is the startle response to the prepulse/pulse cycle.

Social interaction in the Crawley's test. The working unit consisted of a rectangular box with transparent walls, divided into three compartments by transparent partitions (Panlab/Harvard Apparatus, Spain). In the outer compartments, identical wire cylinders were located. Above this area, a Smart video camera (Panlab/Harvard Apparatus, Spain) was installed to record animal's movement in real time.

The experiment was carried out in three steps.

Step 1 - the experimental animal was placed in the central compartment and kept there for 5 min for habituation in the new environment.

Step 2 - an unrelated animal (partner 1 ) is brought into cylinder 1; the experimental animal is placed in the central compartment and stays in the box for $8 \mathrm{~min}$; 
this stage is aimed at investigating the animal's social interest.

Step 3 - another unrelated animal (partner 2) is placed in cylinder 2; the experimental animal is placed in the central compartment and stays in the box for $8 \mathrm{~min}$; this stage is aimed at monitoring social memory and behavior of the animal in gaining new experience.

The time of staying in each of the three compartments and the number of entries into each compartment was monitored [19, 20].

Conditioned reflex of passive avoidance. The behavioral model of the conditioned reflex of passive avoidance (CRPA) is based on the context-related fear; the model is commonly used to assess the formation and reproduction of memory in various models of learning. The setup consisted of a Shuttle Box LE918 chamber (Panlab/Harvard Apparatus, Spain) with an illuminated and dark compartments (each $25 \times 40 \times 25 \mathrm{~cm}$ in size) with floor made of metal rods separated by a guillotine door.

The experiment involved two stages.

The first stage was the development of the CRPA: the experimental animal was placed in the lit section with its tail pointing toward the closed door. After $120 \mathrm{~s}$ the guillotine door was opened and the animal, due to its mink reflex, sneaked into the dark chamber (the time of this transition was recorded as latency period 1, LP1). Immediately after that, the door between the compartments was shut, and the animal received an electrical shock applied through the metal rods on the floor $(0.3 \mathrm{~mA}, 3 \mathrm{~s})$.

The second stage was initiated $24 \mathrm{~h}$ later to test the acquired skills. The animal was placed in the illuminated compartment with the door open, and the time of transition into the dark chamber (latency period 2, LP2) was recorded. The overall observation lasted for $180 \mathrm{~s}$.

Recalling the memory of the electric shock was evaluated by the difference in the latency durations before and after the CRPA had been developed (LP2-LP1).

Statistical analysis. The results are presented as the mean \pm error of the mean

Figure 1. Gradation of audiogenic seizures in mice:

(a) 3 points, animal falls on its side, there are clonic seizures of the fore- and hind limbs (arrows); (b) 4 points, animal falls on its side, asymmetric tonic seizures of the forelimbs (arrow) and clonic seizures of the hind limbs and compared by the one- and two-way ANOVA (F) followed by post-hoc comparison of the sample means (the Newman-Keuls test).

\section{Results}

Audiogenic stimulation. During the experiment, a total of 79 mice (both males and females) aged 2030 days were tested (Table 1). Following the audiogenic stimulation, two mice developed the "circus movements" (1 point); in one mouse, asymmetric tonic seizures of the forelimbs and clonic seizures of the hind limbs with a fall on the side were observed (4 points) (Figure 1). No difference between the WT animals and those with the mutant Sip1 gene was found $\left(F_{2.73}=0.24 ; p=0.79\right)$.

General health and reflexes. In the population of Sip1(+/-) mice, there were no physical abnormalities, changes in the body weight, or fur baldness. However, $14 \%$ of the males had no vibrissae. In addition, the disturbance of the hind limb extension reflex was more common in this group $(21 \%)$ compared with the WT group (0\%) (Figure 2, Table 2).

In our study, mice homozygous for the Sip1 gene did not reach the age of two months: their average life span was $39 \pm 13$ days, so further behavioral studies were conducted only with the group of males with the Sip1(+/-) genotype and with the WT males.

Table 1

Response to audiogenic stimulation in wild type mice and the Sip1 gene mutant mice

\begin{tabular}{|c|c|c|c|c|c|}
\hline & & The 0 & urrence rat & & \\
\hline & type & $\begin{array}{c}\text { Excess } \\
\text { motor activity }\end{array}$ & $\begin{array}{l}\text { Seizure } \\
\text { episodes }\end{array}$ & $\begin{array}{l}\text { Lethal } \\
\text { outcome }\end{array}$ & of animals \\
\hline & Wild type & 0 & 0 & 0 & 9 \\
\hline $\begin{array}{l}\text { Males } \\
(n=29)\end{array}$ & $\operatorname{Sip} 1(+/-)$ & 0 & 0 & 0 & 17 \\
\hline & $\operatorname{Sip} 1(-/-)$ & 0 & 0 & 0 & 3 \\
\hline & Wild type & $6.5 \pm 4.5$ & $3.2 \pm 3.2$ & 0 & 31 \\
\hline Females & $\operatorname{Sip} 1(+1-)$ & 0 & 0 & 0 & 15 \\
\hline & $\operatorname{Sip} 1(-/-)$ & 0 & 0 & 0 & 4 \\
\hline
\end{tabular}
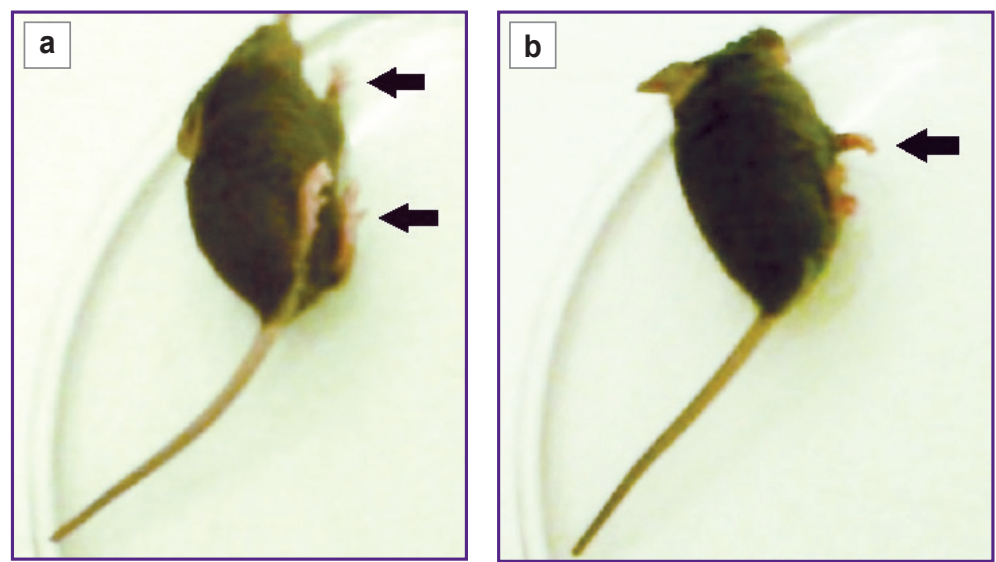


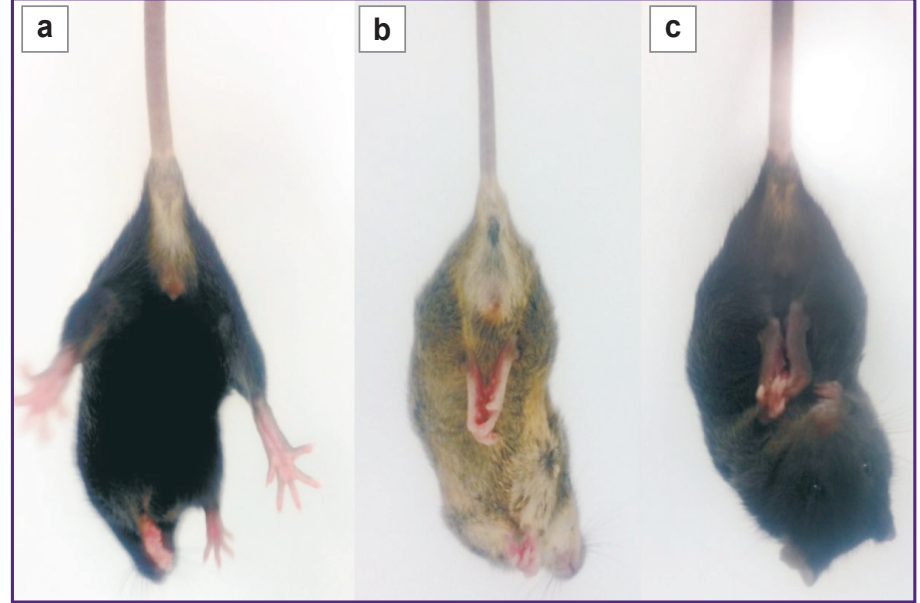

Figure 2. Abnormal hind limb extension reflex in mice heterozygous for the Sip1(+/-) gene (hind limb clasping): (a) the normal reflex; (b), (c) examples of an abnormal reflex

Table 2

General health indices and sensorimotor parameters in wild type mice and the Sip1 gene mutant mice

\begin{tabular}{|c|c|c|}
\hline \multirow{2}{*}{ Parameters } & \multicolumn{2}{|c|}{ Genotype } \\
\hline & Wild type & $\operatorname{Sip} 1(+\mid-)$ \\
\hline \multicolumn{3}{|l|}{ General health indices } \\
\hline Body weight (g) & $25.1 \pm 0.6$ & $23.4 \pm 0.7$ \\
\hline Poor skin condition (\%) & 0 & 0 \\
\hline Bald spots (\%) & 0 & 0 \\
\hline Lack of vibrissae (\%) & 0 & 14 \\
\hline Fur bristling (\%) & 0 & 0 \\
\hline Physical abnormalities (\%) & 0 & 0 \\
\hline Abnormal reflex of hind limb extension (\%) & 0 & 21 \\
\hline \multicolumn{3}{|l|}{ Sensorimotor parameters } \\
\hline Time before leaving the circle $30 \mathrm{~cm}$ in diameter (s) & $3.6 \pm 0.3$ & $4.4 \pm 0.5$ \\
\hline \multicolumn{3}{|l|}{ Time of walking on a balance beam (s): } \\
\hline flat, $3 \mathrm{~cm}$ wide & $11.9 \pm 1.6$ & $20.3 \pm 8.2$ \\
\hline flat, $2 \mathrm{~cm}$ wide & $9.1 \pm 1.4$ & $9.8 \pm 1.9$ \\
\hline flat, $1 \mathrm{~cm}$ wide & $10.4 \pm 2.2$ & $16.3 \pm 8.1$ \\
\hline round, $3 \mathrm{~cm}$ in diameter & $21.2 \pm 9.7$ & $17.2 \pm 8.0$ \\
\hline round, $0.5 \mathrm{~cm}$ in diameter & $98.7 \pm 11.5$ & $84.1 \pm 13.5$ \\
\hline Hanging on the wire (s) & $114.5 \pm 3.8$ & $110.0 \pm 8.6$ \\
\hline Turning around in the cylinder (s) & $12.8 \pm 2.1$ & $22.1 \pm 7.7$ \\
\hline Turning around on the inclined screen (s) & $10.5 \pm 1.9$ & $19.1 \pm 7.9$ \\
\hline
\end{tabular}

The ability to perform sensorimotor tasks did not differ between the two groups of mice. This result pertains to the time of leaving the circle $\left(F_{1.28}=1.72 ; p=0.19\right)$, the walking on a flat beam $3 \mathrm{~cm}$ wide $\left(F_{1.28}=1.16 ; p=0.29\right)$, $2 \mathrm{~cm}$ wide $\left(F_{1.28}=0.07 ; p=0.78\right)$, and $1 \mathrm{~cm}$ wide $\left(F_{1.28}=0.56\right.$; $p=0.46$ ), the walking on a round bar of $3 \mathrm{~cm}$ in diameter $\left(F_{1.28}=0.09 ; p=0.76\right)$ and $0.5 \mathrm{~cm}$ in diameter $\left(F_{1.28}=0.68\right.$; $\mathrm{p}=0.42)$, the time of hanging on the wire $\left(\mathrm{F}_{1.28}=0.25\right.$; $p=0.62)$, the time of turning around on an inclined screen $\left(F_{1.28}=1.27 ; p=0.27\right)$ and the turning around in the cylinder $\left(F_{1.28}=1.56 ; p=0.22\right)$.

The light-dark test. There were no differences between the Sip1(+/-) and WT groups in the latent period duration before the animal sneaked into the dark compartment $\left(F_{1.12}=0.23 ; p=0.64\right)$ and the number of entries into the compartments $\left(F_{1.12}=2.48 ; p=0.14\right)$. However, regarding the time spent in the lit or dark compartments, it was found that the Sip1(+/-) mice spent more time in the dark compartment (276.1 $\pm 15.2 \mathrm{~s})$ compared with the WT mice $(204.7 \pm 15.2 s)\left(F_{1.12}=5.66 ; p=0.03\right)$.

The open field test. The Sip1(+/-) animals did not differ from the WT animals in terms of their motor activity: the total distance traveled $\left(\mathrm{F}_{1.48}=1.65\right.$; $p=0.21)$, the average speed of movement $\left(F_{1.48}=1.7\right.$; $p=0.19)$, and the estimated exploration-orientation activity, i.e. the total number of rearings $\left(F_{148}=2.3\right.$; $p=1.14)$. In addition, there was no difference in the emotional behavior of these animals, as evidenced by the similar number of defecations $\left(F_{1.48}=3.50 ; \quad p=0.07\right)$ and urinations $\left(F_{1.48}=1.03\right.$ $\mathrm{p}=0.32$ ). However, a more specific analysis showed a decrease in the number of rearings in the central zone among the Sip1(+/-) mice $(0.3 \pm 0.1)$ as compared to the WT group $(2.7 \pm 0.8)\left(F_{1.48}=6.18\right.$; $\mathrm{p}=0.02$ ).

Startle reflex. The Sip1(+/-) mice did not differ from the WT animals in terms of intensity of the acoustic startle response $\left(F_{1.20}=0.14 ; p=0.07\right)$, and the PPI value did not change either $\left(F_{120}=0.35\right.$; $p=0.56)$.

Social interaction. In the study of social interest, the presence of an unfamiliar partner had an impact on the time spent in a given compartment $\left(F_{1.26}=8.67 ; p=0.007\right)$ and the number of entries into the compartment $\left(F_{1.26}=7.53 ; p=0.01\right.$ ) (Table 3). Thus, the Sip1(+/-) mice stayed less time in the compartment with an unfamiliar partner (partner 1) as compared to the animals of the WT group $(p=0.03)$; also they made more entries into the empty compartment as compared with the compartment where an unfamiliar partner was sitting. The social memory test did not find any differences between the genotypes $\left(F_{1.26}=0.01 ; p=0.91\right)$ : both $\operatorname{Sip} 1(+/-)$ and WT mice spent more time in the compartment with a new unfamiliar partner (partner 2) than in the compartment with the previously known partner (partner 1) $(p=0.005)$.

Conditioned reflex of passive avoidance. In developing the reflex of passive avoidance, both experimental groups showed an increased latent period before going to the dark compartment on day 2 as compared to day $1\left(F_{1.86}=68.11 ; p<0.001\right)$ (Figure 3$)$. Yet, there was no difference in the latency between the Sip1(+/-) and WT mice $\left(F_{1.43}=0.02 ; p=0.89\right)$, which indicates similar levels of learning. 
Table 3

The behavior indices in mice tested for social interaction

\begin{tabular}{lccccc}
\hline \multirow{2}{*}{ Test } & \multirow{2}{*}{ Compartment } & \multicolumn{2}{c}{ Time spent in compartment (s) } & \multicolumn{2}{c}{ Number of entries into compartment } \\
\cline { 3 - 6 } & & Wild type & Sip1(+/-) & Wild type & Sip1(+/-) \\
\multirow{2}{*}{ Social interest } & Empty & $188.6 \pm 30.9$ & $206.2 \pm 43.4$ & $84.6 \pm 13.4$ & $131.9 \pm 37.9$ \\
\cline { 2 - 6 } & Partner 1 & $127.6 \pm 11.9$ & $74.5 \pm 27.5^{*}$ & $55.5 \pm 8.3$ & $36.1 \pm 11.1^{\#}$ \\
\multirow{2}{*}{$\begin{array}{l}\text { Novel social } \\
\text { experience }\end{array}$} & Partner 1 & $132.6 \pm 20.8$ & $126.9 \pm 30.4$ & $36.0 \pm 5.3$ & $51.1 \pm 10.1$ \\
\cline { 2 - 6 } & Partner 2 & $213.9 \pm 32.2$ & $213.1 \pm 23.3$ & $59.3 \pm 4.8$ & $140.2 \pm 50.5$ \\
\hline
\end{tabular}

* Significant difference as compared to the wild type group; \# compared to the empty compartment values; $p<0.05$.

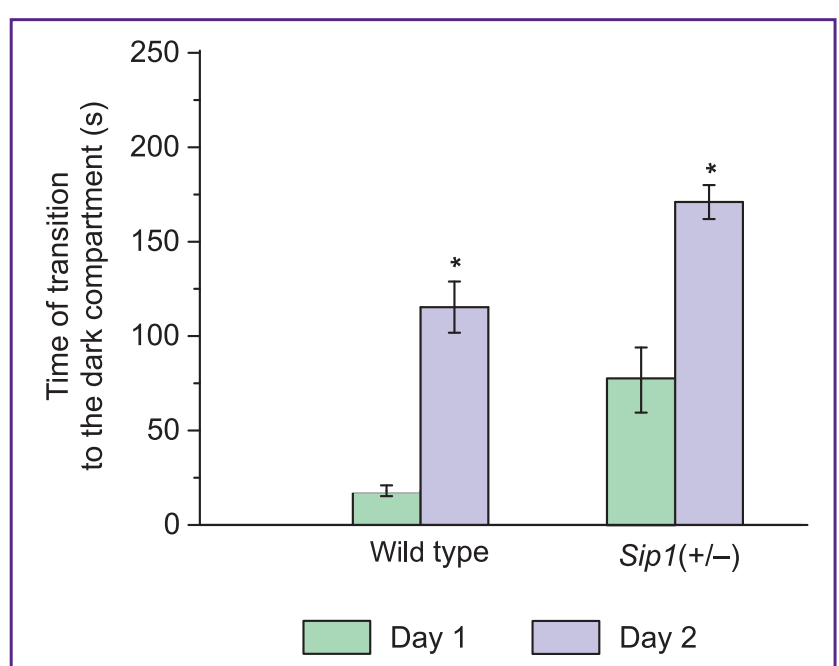

Figure 3. Time of transition to the dark compartment in the development of the conditioned reflex of passive avoidance in Sip1(+/-) and wild type mice

* Significant difference in values between the days 1 and 2; $p<0.05$

\section{Discussion}

This study is aimed at revealing an impact of the mutant allele of the Sip1 gene on health and CNS functions in mice. The modern protocol on behavioral phenotyping of murine mutants (the SHIRPA protocol) includes more than 40 parameters and allows for detecting various disorders of the neuromuscular, sensory and vegetative systems of the body [21].

At the first stage (screening) of our study, preliminary assessment of the overall health, motor and sensory functions was conducted. It allowed us to avoid false interpretation of further - more complex - behavioral tasks. All the mice studied had a good condition of the skin, no bald spots or fur bristling.

Intact adult rodents lifted by the tail and then slowly lowered to a horizontal surface spread all four limbs in anticipation of a contact [22]. According to our results, the presence of one mutant allele of the Sip1 gene resulted in an abnormal limb extension reflex (see Figure 2). The similar pattern was observed in mice with cerebellar, basal ganglia or neocortex lesions, as well as in transgenic murine models of Alzheimer's disease [22]. It was suggested that the mechanism underlying these disorders (which includes the cerebello-cortico-reticular and corticostriato-pallidoreticular pathways) might be associated with alterations of norepinephrine and serotonin transmission. In addition, a specific CNS lesion caused by neocortex and cerebellum degeneration was found in mice lacking the Atg7 gene and demonstrating a deficient limb extension reflex [23]. Limb clasping and a bat-like pose were observed in transgenic mice with expression of the cytoplasmic prion protein Prp and decreased thickness of the neocortex [24].

It cannot be ruled out that the absence of vibrissae in the Sip1(+/-) mice found in this study could have affected the results of behavioral testing. It is known that a deficit of sensory information at an early age can affect the behavior pattern in adults. In rats with their vibrissae trimmed during the three postnatal days, structural and functional somatosensory abnormalities were found; in addition, their behavior was characterized by a greater exploration activity and more frequent social interactions [25]. However, another report showed that the exploration activity of adult Wistar rats whose vibrissa had been removed between the $9^{\text {th }}$ and $20^{\text {th }}$ postnatal days was less variable compared to control rats [26]. Notably, the removal of vibrissae on the $2^{\text {nd }}$ to the $9^{\text {th }}$ day of life did not cause such changes [27]. Therefore, the absence of vibrissae might be the cause of the decreased number of rearing episodes in the Sip1(+/-) mice as found in the open field test.

As mentioned above, abnormalities in brain development are now increasingly viewed as possible causes of epilepsy, development problems, neurological deficits and mental retardation in humans [1]. Audiogenic seizures in rodents in response to a sound impulse are the commonly used models of generalized convulsive epilepsy (grand mal) in humans $[15,28]$. In the present study, we found no effect of the mutant allele of the Sip1 gene on magnitude of audiogenic seizures.

The light-dark test was used to assess the level of anxiety in the experimental animals. In this test, the time spent in the lit and dark compartments, as well as 
the number of transitions between them is measured [29]. The Sip1(+/-) mice spent more time in the dark compartment, which indicated an increased anxiety of the animals.

The open field test is widely used to study the motor activity (the distance traveled), the exploration activity (number of rearings) and the level of anxiety (time spent in the central field) under the mild stress conditions [30, 31]. The Sip1(+/-) mice performed significantly fewer rearings in the central field compared to the animals of the WT group, which indirectly indicated their increased anxiety and agrees with our results obtained in the lightdark test.

The startle response test is used to study a number of CNS functions including adaptation to the sound and prepulse inhibition (a decrease in the startle response after a preliminary subthreshold impulse, which reflects the filtration of sensory inputs in the CNS); those functions are affected in schizophreniform patients The PPI concept suggests that the startle response to prepulse + pulse (given within a $60 \mathrm{~ms}$ interval) will be lessened as compared with the startle in response to a single pulse. The startle reflex - a relatively simple reflex of the skeletal musculature - is a consequence of fright and apparently serves to prevent potential damage to the animal $[32,33]$. The absence of changes in the magnitude of the startle reaction and PPI in the Sip1(+/-) mice indicates normal auditory perception and no change in the emotional state of fear in these animals.

To assess the effect of the mutant allele of the Sip1(+/-) gene on cognitive functions and the learning ability, we studied the level of memory associated with the conditioned reflex of passive avoidance. The results showed that the latent periods preceding the transition into the dark compartment differed between days 1 and 2 of the study. This effect was similar for both tested groups thus indicating the identical learning ability of the Sip1(+/-) and WT mice.

The next stage of behavioral phenotyping was an assessment of the more delicate functions of the nervous system associated with the individual and social behavior of animals.

Social behavior is the behavior that manifests when at least one other representative of the same species is present. This includes all variants of inter-male interactions, reproductive (sexual) and parental behavior [34]. The term "social recognition" as a phenomenon and an experimental paradigm was introduced in the $1980 \mathrm{~s}$. [35]. It is based on an unconditional behavioral response (interest) of the animal when an unfamiliar partner is placed nearby. In our study on social interest and social recognition, we found a decrease in the social activity in the Sip1(+/-) mice compared to WT: in the presence of an unknown social partner, these mice preferred to stay in the empty compartment. The study of the movements aimed at obtaining novel social experience revealed no differences between the tested groups of mice. The behavior of the experimental animals was considered normal as the mice sought to spend more time with the new partner than with the familiar one. This behavior is consistent with the standards of normal social memory.

The similar results were obtained by a group of Japanese scientists who tried to create a model of MowatWilson syndrome: they found an increased level of anxiety and impaired communication in Sip1 mice [36]. In contrast to our results, they showed a decrease in the motor activity of the mice; this difference might be due to the fact that the open field testing time in their setup was $1 \mathrm{~h}$.

Our results suggest a putative molecular mechanism that could explain the role of the Sip1 gene in the regulation of sensorimotor functions and anxiety. The transcription factor Sip1 has a high level of expression in post-mitotic neurons of the neocortex. The conditional deletion of Sip1 in the early neurons causes premature generation of neurons in the upper layers at the expense of neurons of the lower layers, as well as premature and increased generation of glial precursors, and enhanced postnatal astrocytogenesis. Premature formation of neurons of the upper layers is accompanied by increased expression of neurotrophin-3. The Sip1 gene inhibits the formation of signaling factors in post-mitotic neurons, which gives a feedback signal that makes the predecessors regulate the timing of cell switching, the number of neurons and the enhancement of glial corticogenesis [12]. In addition, expression of Sip1 is observed in highly differentiated CNS cells, such as serotonergic and dopaminergic neurons [37]; dysfunction of these cells is associated with the development of anxiety [38, 39].

Thus, disturbances of the timely neuronal migration and differentiation, regulated by the Sip1 factor, can lead to increased emotional lability and abnormal sensorimotor reactions in adult animals.

\section{Conclusion}

The presence of the mutant allele of the Sip1 gene did not affect the motor activity, learning ability, startle response, or the level of prepulse inhibition in mice, but had some effect on the neurological function, anxiety and social interest in these animals. The results suggest that a mutation in the Sip1 gene leads to a disruption of neurofunctional interactions thus leading to a neurological deficit and changes in the behavioral response under mild stress conditions.

Financial support. The article was supported by the Russian Science Foundation (grant No.15-14-10021) on the priority line of activities "Conducting fundamental research involving young scientists".

Conflict of interest. The authors declare no conflict of interest.

\section{References}

1. Fernández V., Llinares-Benadero C., Borrell V. Cerebral cortex expansion and folding: what have we learned? 
EMBO J 2016; 35(10): 1021-1044, https://doi.org/10.15252/ embj.201593701.

2. Elsen G.E., Hodge R.D., Bedogni F., Daza R.A.M., Nelson B.R., Shiba N., Reiner S.L., Hevner R.F. The protomap is propagated to cortical plate neurons through an Eomes-dependent intermediate map. Proc Natl Acad Sci USA 2013; 110(10): 4081-4086, https://doi.org/10.1073/ pnas. 1209076110.

3. De Juan Romero C., Borrell V. Coevolution of radial glial cells and the cerebral cortex. Glia 2015; 63(8): 13031319, https://doi.org/10.1002/glia.22827.

4. Goossens S., Janzen V., Bartunkova S., Yokomizo T., Drogat B., Crisan M., Haigh K., Seuntjens E., Umans L., Riedt T., Bogaert P., Haenebalcke L., Berx G., Dzierzak E., Huylebroeck D., Haigh J.J. The EMT regulator Zeb2/Sip1 is essential for murine embryonic hematopoietic stem/progenitor cell differentiation and mobilization. Blood 2011; 117(21): 5620-5630, https://doi.org/10.1182/blood-2010-08-300236.

5. Manthey A.L., Lachke S.A., FitzGerald P.G., Mason R.W., Scheiblin D.A., McDonald J.H., Duncan M.K. Loss of Sip1 leads to migration defects and retention of ectodermal markers during lens development. Mech Dev 2014; 131: 86-110, https://doi.org/10.1016/j. mod.2013.09.005.

6. Teraishi M., Takaishi M., Nakajima K., Ikeda M., Higashi Y., Shimoda S., Asada Y., Hijikata A., Ohara O., Hiraki Y., Mizuno S., Fukada T., Furukawa T., Wakamatsu N., Sano S. Critical involvement of ZEB2 in collagen fibrillogenesis: the molecular similarity between Mowat-Wilson syndrome and Ehlers-Danlos syndrome. Sci Rep 2017; 7: 46565, https://doi. org/10.1038/srep46565.

7. Garavelli L., Mainardi P. Mowat-Wilson syndrome. Orphanet J Rare Dis 2007; 2(1): 42, https://doi. org/10.1186/1750-1172-2-42.

8. Srivatsa S., Parthasarathy S., Molnár Z., Tarabykin V. Sip1 downstream Effector ninein controls neocortical axonal growth, ipsilateral branching, and microtubule growth and stability. Neuron 2015; 5(5): 998-1012, https://doi. org/10.1016/j.neuron.2015.01.018.

9. Turovskaya M.V., Babaev A.A., Zinchenko V.P., Epifanova E.A., Borisova E.V., Tarabykin V.S., Turovsky E.A. Sip-1 mutations cause disturbances in the activity of NMDAand AMPA-, but not kainate receptors of neurons in the cerebral cortex. Neurosci Lett 2017; 650: 180-186, https://doi. org/10.1016/j.neulet.2017.04.048.

10. Higashi Y., Maruhashi M., Nelles L., Van de Putte T., Verschueren K., Miyoshi T., Yoshimoto A., Kondoh H., Huylebroeck D. Generation of the floxed allele of the SIP1 (Smad-interacting protein 1) gene for Cre-mediated conditional knockout in the mouse. Genesis 2002; 32(2): 82-84, https:// doi.org/10.1002/gene.10048.

11. Goebbels S., Bormuth I., Bode U., Hermanson O., Schwab M.H., Nave K.-A. Genetic targeting of principal neurons in neocortex and hippocampus of NEX-Cre mice. Genesis 2006; 44(12): 611-621, https://doi.org/10.1002/dvg.20256.

12. Seuntjens E., Nityanandam A., Miquelajauregui A., Debruyn J., Stryjewska A., Goebbels S., Nave K.A., Huylebroeck D., Tarabykin V. Sip1 regulates sequential fate decisions by feedback signaling from postmitotic neurons to progenitors. Nat Neurosci 2009; 12(11): 1373-1380, https:// doi.org/10.1038/nn.2409.

13. Gorski J.A., Talley T., Qiu M., Puelles L., Rubenstein J.L., Jones K.R. Cortical excitatory neurons and glia, but not GABAergic neurons, are produced in the Emx1expressing lineage. J Neurosci 2002; 22(15): 6309-6314.

14. Chabrol E., Navarro V., Provenzano G., Cohen I., Dinocourt C., Rivaud-Péchoux S., Fricker D., Baulac M., Miles R., Leguern E., Baulac S. Electroclinical characterization of epileptic seizures in leucine-rich, glioma-inactivated 1-deficient mice. Brain 2010; 133(9): 2749-2762, https://doi. org/10.1093/brain/awq171.

15. Semiokhina A.F., Fedotova I.B., Poletaeva I.I. Rats of Krushinsky-Molodkina strain: studies of audiogenic epilepsy, vascular pathology and behavior. Zhurnal vysshei nervnoi deyatelnosti imeni I.P. Pavlova 2006; 56(3): 298-316.

16. Silva A.F., Sousa D.S., Medeiros A.M., Macêdo P.T., Leão A.H., Ribeiro A.M., Izídio G.S., Silva R.H. Sex and estrous cycle influence diazepam effects on anxiety and memory: Possible role of progesterone. Prog Neuropsychopharmacol Biol Psychiatry 2016; 70: 68-76, https://doi.org/10.1016/j. pnpbp.2016.05.003.

17. Kiryk A., Aida T., Tanaka K., Banerjee P., Wilczynski G.M., Meyza K., Knapska E., Filipkowski R.K., Kaczmarek L., Danysz W. Behavioral characterization of GLT1 (+/-) mice as a model of mild glutamatergic hyperfunction. Neurotox Res 2008; 13(1): 19-30, https://doi.org/10.1007/bf03033364.

18. Rosen J.B., Schulkin J. From normal fear to pathological anxiety. Psychol Rev 1998; 105(2): 325-350, https://doi.org/10.1037/0033-295x.105.2.325.

19. Crawley J.N. Designing mouse behavioral tasks relevant to autistic-like behaviors. Ment Retard Dev Disabil Res Rev 2004; 10(4): 248-258, https://doi.org/10.1002/mrdd.20039.

20. Kaidanovich-Beilin O., Lipina T., Vukobradovic I., Roder J., Woodgett J.R. Assessment of social interaction behaviors. J Vis Exp 2011; 48: 2473, https://doi. org/10.3791/2473.

21. Crawley J.N. Behavioral phenotyping strategies for mutant mice. Neuron 2008; 57(6): 809-818, https://doi. org/10.1016/j.neuron.2008.03.001.

22. Lalonde R., Strazielle C. Motor performance and regional brain metabolism of spontaneous murine mutations with cerebellar atrophy. Behav Brain Res 2001; 125(1-2): 103-108, https://doi.org/10.1016/s0166-4328(01)00276-5.

23. Komatsu M., Waguri S., Chiba T., Murata S., Iwata J., Tanida I., Ueno T., Koike M., Uchiyama Y., Kominami E., Tanaka K. Loss of autophagy in the central nervous system causes neurodegeneration in mice. Nature 2006; 441(7095): 880-884, https://doi.org/10.1038/nature04723.

24. Wang X., Bowers S.L., Wang F., Pu X., Nelson R.J., $\mathrm{Ma}$ J. Cytoplasmic prion protein induces forebrain neurotoxicity. Biochim Biophys Acta 2009; 1792(6): 555-563, https://doi. org/10.1016/j.bbadis.2009.02.014.

25. Lee L.-J., Chen W.-J., Chuang Y.-W., Wang Y.-C. Neonatal whisker trimming causes long-lasting changes in structure and function of the somatosensory system. Exp Neurol 2009; 219(2): 524-532, https://doi.org/10.1016/j. expneurol.2009.07.012.

26. Shishelova A.Yu., Aliev R.R., Raevsky V.V. Early sensory experience determines variety of exploratory behavior in adult age. Eksperimentalnaya psikhologiya 2015; 8(1): 73-84.

27. Shishelova A.Y., Raevskii V.V., Aliev R.R. Effect of early sensory experience on the exploratory activity in adult animals. Doklady Biological Sciences 2016; 468(1): 101-103, https:// doi.org/10.1134/s0012496616030029.

28. Krushinskiy L.V. The new in the study of experimental 


\section{ADVANCED RESEARCHES}

epilepsy and its underlying physiological mechanisms. Uspekhi sovremennoi biologii 1949; 28: 108-133.

29. Hascoët M., Bourin M., Nic Dhonnchadha B.Á. The mouse ligth-dark paradigm: a review. Prog Neuropsychopharmacol Biol Psychiatry 2001; 25(1): 141-166, https://doi.org/10.1016/s0278-5846(00)00151-2.

30. Denenberg V.H. Open-field behavior in the rat: what does it mean? Ann N Y Acad Sci 1969; 159(3): 852-859, https://doi.org/10.1111/j.1749-6632.1969.tb12983.x.

31. Bailey K.R., Rustay N.R., Crawley J.N. Behavioral phenotyping of transgenic and knockout mice: practical concerns and potential pitfalls. ILAR J 2006; 47(2): 124-131, https://doi.org/10.1093/ilar.47.2.124.

32. Popova N.K., Barykina N.N., Pliusnina I.Z. Alekhina T.A., Kolpakov V.G. Manifestation of fear response in rats genetically predisposed to various kinds of defense behavior. Rossiiskii fiziologicheskii zhurnal imeni I.M. Sechenova 1999; 1: 99-104.

33. Tibeykina M.A. Genetiko-fiziologicheskie osobennosti akusticheskoy reaktsii vzdragivaniya: vzaimosvyaz's drugimi formami povedeniya. Dis. ... kand. biol. nauk [Genetic and physiological properties of acoustic startle response: relationship with other forms of behavior. $\mathrm{PhD}$ dissertation]. Novosibirsk; 2008.

34. Amikishieva A.V. Behavioral phenotyping: up-to-date methods and equipment. Informatsionnyy vestnik VOGiS 2009; 13(3): 529-542.

35. Thor D.H., Holloway W.R. Anosmia and play fighting behavior in prepubescent male and female rats. Physiol Behav 1982; 29(2): 281-285, https://doi.org/10.1016/00319384(82)90016-6.

36. Takagi T., Nishizaki Y., Matsui F., Wakamatsu N., Higashi Y. De novo inbred heterozygous Zeb2/Sip1 mutant mice uniquely generated by germ-line conditional knockout exhibit craniofacial, callosal and behavioral defects associated with Mowat-Wilson syndrome. Hum Mol Genet 2015; 24(22): 6390-6402, https://doi.org/10.1093/hmg/ ddv350.

37. Nishizaki Y., Takagi T., Matsui F., Higashi Y. SIP1 expression patterns in brain investigated by generating a SIP1EGFP reporter knock-in mouse. Genesis 2013; 52(1): 56-67, https://doi.org/10.1002/dvg.22726.

38. Overstreet D.H., Commissaris R.C., De La Garza R., File S.E., Knapp D.J., Seiden L.S. Involvement of 5-HT1A receptors in animal tests of anxiety and depression: evidence from genetic models. Stress 2003; 6(2): 101-110, https://doi. org/10.1080/1025389031000111311.

39. Naumenko V.S., Ponimaskin E.G., Popova N.K. 5-HT receptor: its role in the regulation of different kinds of behavior. Vavilovskii zhurnal genetiki i selektsii 2016; 20(2): 180-190. 